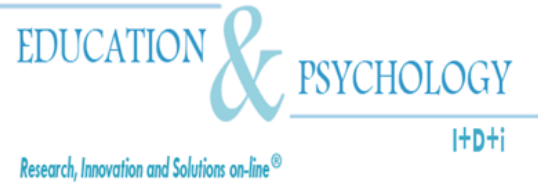

\title{
Advanced numerical-algebraic thinking: Constructing the concept of covariation as a prelude to the concept of function
}

\author{
Fernando Hitt ${ }^{1}$ \& Christian Morasse $^{2}$ \\ ${ }^{1}$ Département de Mathématiques, Université du Québec à Montréal, \\ Montréal/Québec \\ ${ }^{2}$ Collège de Montréal, Montréal/Québec
}

\section{Canada}

Fernando Hitt \& Christian Morasse. 201, avenue du Président-Kennedy, 5e étage, Département de mathématiques, Local PK-5920, Montréal/Québec. Canada. E-mail: hitt.fernando@uqam.ca, morasse.christian@gmail.com

(C) Education \& Psychology I+D+i and Editorial EOS (Spain) 


\begin{abstract}
Introduction. In this document we stress the importance of developing in children a structure for advanced numerical-algebraic thinking that can provide an element of control when solving mathematical situations. We analyze pupils' conceptions that induce errors in algebra due to a lack of control in connection with their numerical thinking. We offer a detailed critique of a research group who promote the movement of introducing algebra in primary school ("Early Algebra").

Method. In this collaborative research, we show how to promote advanced numericalalgebraic thinking through experimentation with certain activities (problem situations) in two groups of secondary students (grade 9), with 24 and 36 students, respectively. We use a specific methodology for collaborative learning, scientific debate and self-reflection (ACODESA methodology).
\end{abstract}

Results. The pupils in this study constructed covariational reasoning as a prelude to the function concept. They also developed control elements that helped them in the process of solving problem situations.

Discussion. Numerical reasoning is essential to giving meaning to the syntactic processes that, if manipulated or conceived of incurrectly, can lead to an error in a given situation. Advanced numerical-algebraic thinking helps us develop sensitivity to contradiction, enabling us to detect error. We believe that working with manipulative materials and producing functional representations that can evolve into institutional ones, and using collaborative learning with scientific debate and self-reflective reasoning (ACODESA methodology), can help pupils to more easily retain their mathematical concepts over time.

Keywords. Numerical and algebraic reasoning, functional representations, covariational reasoning, problem situation, ACODESA methodology.

Received: 12/18/08 Initial Acceptance: 01/28/09 Final Acceptance: 02/24/09 


\section{Resumen}

Introducción. En este documento enfatizamos la importancia de desarrollar en los niños un pensamiento numérico-algebraico avanzado, que pueda proporcionar un elemento de control en los procesos de resolución de situaciones matemáticas. Se analizan concepciones de algunos alumnos que los induce a cometer errores en álgebra, por una falta de control por no recibir apoyo de su pensamiento numérico. Hacemos una crítica puntual a un grupo de investigación que se identifica con el movimiento acerca de la introducción del álgebra en la escuela primaria ("Early Algebra").

Método. En esta investigación, en colaboración, mostramos que es factible promover un pensamiento numérico-algebraico avanzado, en una experimentación de actividades (situaciones problema) con dos grupos de secundaria (grado 9), respectivamente con 24 y 36 alumnos, utilizando una metodología específica sobre aprendizaje en colaboración, debate científico y auto-reflexión (metodología ACODESA).

Resultados. Los alumnos en este estudio, lograron construir el concepto de covariación como preludio al concepto de función, y desarrollar elementos de control que les sirvió en la resolución de las situaciones problema propuestas en esta experimentación.

Conclusiones. El pensamiento numérico es esencial para proporcionar a los alumnos significados sobre sus procesos sintácticos que, por una mala manipulación o por una concepción, en una situación dada, puede guiarlos a error. El pensamiento numérico-algebraico avanzado, nos ayuda en el desarrollo de una sensibilidad a la contradicción para detectar el error. El trabajo con materiales, un aprendizaje colaborativo, debate científico y auto-reflexión (metodología ACODESA) permite una construcción más sólida de los conceptos matemáticos y posiblemente proporcionará una mayor retención de esos conceptos a largo plazo.

Palabras clave: Razonamiento numérico y algebraico, representaciones funcionales, razonamiento covariacional, situacion problema, metodologia ACODESA.

Recibido: 18/12/08 Aceptación inicial: 28/01/08 Aceptación final: 24/02/09 


\section{Introduction}

If we start off with the fact that numerical thinking is essential for the development of mathematical thought, then, for the learning of mathematics, this type of thinking is one of the first abilities we must develop in pupils. Verschaffel and De Corte (1996) indicate that the important changes in mathematics curricula in primary school have to do with:

1) number concepts and number sense,

2) the meaning of arithmetic operations,

3) mastery of basic arithmetic facts,

4) mental and written computation, and

5) word problems as applications of numerical and arithmetical knowledge and skills.

We could ask if a pupil who has developed the competences involved in these five points has constructed adequate numerical thinking for developing new mathematical competences in secondary school. Generally, it is considered very important to equip the pupil with meaning, to construct numerical thinking that will serve as a support when he or she faces algebraic tasks that demand the production of syntactic processes. Is this ability developed in primary school?

One of the big problems in the transition from arithmetic to algebra is that pupils consider algebra as another type of knowledge, where numerical thinking does not have direct application. A large number of studies have been dedicated to analyzing students' algebraic errors, called "buggy algorithms" (see for example, Carton et al. 2001/02; Donovan \& Pellegrino, 2003; Hatano et al. 1996;); we can explain where these errors come from, but the difficulty arises when we try to give a solution to promote success at secondary school. Our position throughout this document is on the importance of promoting advanced numericalalgebraic thinking in pupils.

From our point of view, the so-called buggy algorithms actually become constituted as knowledge! Thus, the pupil has constructed knowledge around an algorithm contradictory to mathematical logic. Then, how can he possibly think about his errors? Saboya et al. (2006) stated: "Faced with a mathematical production, the pupil should be able to check his result, to judge its coherency and the validity and rigor of his process, and be able to engage reflective- 
ly in a resolution process, showing judgment. These actions represent the pupil's control over the mathematical activity and demonstrate his or her latest acquisition, the development of mathematical rationality" (p. 1).

Given this line of thought, we see that one of the main problems is that the pupil lacks control over the processes he is engaged in, and once engaged in a numerical or algebraic process, he does not show aspects of anticipation that allow him to control the situation in which he is immersed. A natural question that arises is how to solve learning difficulties in algebra. Let us look at one approach before we state ours.

What kind of approach is better for overcoming learning difficulties in algebra?

James Kaput introduced his ideas about early learning of calculus in 1990 (1990, Vol. I, p. 228). In a poster session, Kaput showed some videos about SIMCALC and mentioned intuitive ideas as an important source for developing mathematics. Selon Tall (2008, p. 188) states: "[Kaput] focused on the way in which younger children have an intuitive sense of concepts such as distance, velocity, acceleration, which could be utilized in conjunction with computer simulation to study aspects of calculus at a far earlier age."

Kaput's work relating to intuitive calculus led him to analyze problems related to the learning of algebra. In 1998, he wrote about "Transforming Algebra from an Engine of Inequity to an Engine of Mathematical Power by "Algebrafying" the K-12 Curriculum". In this document, he promotes research about "early algebra". His analysis considered five approaches to learning algebra:

1. Algebra as generalizing and formalizing patterns and regularities, in particular, algebra as generalized arithmetic;

2. Algebra as syntactically guided manipulations of symbols;

3. Algebra as the study of structure and systems abstracted from computations and relations;

4. Algebra as the study of functions, relations and joint variation;

5. Algebra as modeling. 
The movement to "algebrafy" the K-12 Curriculum in the States gave rise to research about this matter and now some results are available. The SERP research agenda (2003) foresaw the type of research needed to understand the problems of learning algebra. They explain:

Students have informal ways of reasoning about problems that can be quite powerful. For instance, consider the following two problems:

As a waiter, Ted gets $\$ 6$ per hour. One night he made $\$ 66$ in tips and earned a total of $\$ 81.90$. How many hours did Ted work?

Versus

$\mathrm{x} * 6+66=81.90$

While only 42 percent of Algebra 1 students can solve the second equation, a full 70 percent can solve the word problem (Koedinger \& Nathan, in press).

Depending on the learning approach, we can induce from this that a significant number of students that could not manage proper manipulation of algebraic symbols are not only missing a certain understanding of algebra, but are also losing their arithmetic abilities.

Some researchers who promote the "Early Algebra" movement consider that it is important to deal with pupils' problems in transitioning from arithmetic to algebra at early ages (see, for example, Carraher Schliemann \& Brizuela, 2000 and Carraher et al., 2006). They try to find algebraic activities that, step by step, allow elementary school pupils to gain control of algebraic thinking. From their point of view, the pupils who work in these environments have the opportunity to continue their studies without much difficulty.

Carraher et al. $(2000,2006)$ propose looking at operations like functions: "We believe there are good reasons for treating arithmetical operations as functions in early mathematics instruction" (2000, p. 3). When working with young children (grade 3) on algebraic notation of variables, the children manage to guess the rule of $n \rightarrow n+3$, and even more complex rules like: $\mathrm{n} \rightarrow \mathrm{n} \times 2-1$ (p.14). We think, as do many researchers, that children are able to generalize processes, and this is the case in the experimentation which Carraher carries out. However, saying that pupils are constructing the function concept is another thing. The children's interventions are clear; they do not understand these processes as covariance processes. Rather, they have the "black box" idea, where something enters the "black box" and leaves it transformed. Although we use the metaphor of the "black box" to introduce the concept of functions, it is not enough for constructing the concept of covariance between variables, es- 
sential to the construction of the function concept. We can corroborate this with the authors' statement that the children had difficulties filling in the following table (Idem, p. 12-13).

The partially completed table for $y=2 x+1$

\begin{tabular}{|c|c|}
\hline $\mathbf{x}$ & $\mathbf{y}$ \\
\hline 1 & \\
\hline 2 & \\
\hline 3 & \\
\hline 4 & \\
\hline 5 & \\
\hline 6 & \\
\hline 7 & \\
\hline 8 & \\
\hline 9 & \\
\hline 10 & \\
\hline 20 & \\
\hline \multicolumn{2}{|c|}{} \\
\hline 30 & \\
\hline 100 & \\
\hline \multicolumn{2}{|c|}{$\mathrm{N}$} \\
\hline
\end{tabular}

Figure 1. Table used in research by Carraher et al.

In the interview with Jennifer and Melissa (in the same study), Jennifer's resistance to using variable $\boldsymbol{x}$ to designate the height of a person, or the money that David has in his pocket, is clear. Let's look at the interview provided by Carraher et al. (2000, p. 17):

David: O.K., now, if I didn't know Alan's height, and I just had to say, "Well, I don't know it so I'll just call it ' $x$ '..."

Melissa: You could guess it.

Jennifer: You could say like, well it would just tell you to say any number.

David: Why don't I use an $x$ and say whatever it is I'll just call it $x$ ? (umm)

Both: (puzzlement)

David: Do you like that idea, or does that feel strange?

Jennifer: It feels strange.

Melissa: No, I pretty much... [unlike her classmate, she is comfortable with using $\mathrm{x}$ in this manner.]

David (addressing Jennifer): It feels strange? 
Jennifer: Yes, 'cause it has to, it has to have a number. 'Cause... Everybody in the World has a height.

Related to the amount of money David has in his pocket, David tried to call it $\mathrm{x}$ and Jennifer answers:

Jennifer: You can't call it $x$ because it has... if he has some money in there, you can't just call it $x$ because you have to count how much money [is] in there.

Jennifer's resistance to the use of the letter $\mathrm{x}$ is clear. A surprising thing to us is David's insistence on using the letter $\mathrm{x}$ to designate the variable. This excerpt, along with the table of values, shows us that the researchers in this study try at all costs to induce the children to use algebraic annotation, even if everything seems to indicate a resistance to that premature use.

These researchers have a very clear tendency towards formalization without attending to semantic aspects necessary for developing algebraic thinking. Why use letters $\mathrm{x}$ or $\mathrm{y}$ for the variables when he could, at that level, use words like "height", for example, to designate any height? After the children write "height" enough times, they themselves will shorten it to h. It seems that these researchers' line of investigation follows a classic approach in teaching algebra notation, but what is surprising is that they want to impose those ideas in grade 3 . This is the imposition of institutional representations, without giving importance to the pupils' spontaneous representations and their evolution. We believe that these kinds of activities in elementary school are going to produce more problems than solutions. Moreover, given that the researchers as teachers conducted this study poorly, it is more difficult to believe that a normal teacher could have a good approach for teaching functions in primary school if he or she does not know about the mathematics curriculum at the secondary level. Their approach is likely to be more procedural than conceptual and there is not much gain in following this approach in learning algebra.

Let us look at another example which is more related to our idea of developing advanced numerical thinking. Barallobres (2004), inspired by Brousseau's (1998) work on the theory of didactic situations and validation processes, implemented an experiment that also takes into account Balacheff's (1987) point of view on pragmatic and intellectual proof. Here is the activity: 
Another example will help clarify our position. We proposed a game with seventhgraders (13 year-olds), where they were asked to find the sum of 10 consecutive numbers chosen arbitrarily by the teacher (the use of calculator was prohibited). The team which managed to find this sum the fastest was declared the winner. The situation was set up in order to encourage evolution towards producing a formula that would be able to produce the sum of any series of 10 consecutive numbers. (p. 298-299)

Barallobres showed that teamwork and debate gave interesting results, stating:

Let us analyze two productions from the class:

...multiply the first number by 10 and add 45. To arrive at this formula, the pupils identified the relations between each number of the series and the first number of this series

... add a 5 to the fifth number in the series". For example, if the series is 34353637 3839404142 43, the sum is 385. In this case, the pupils arrived at this formula through observation of regularities for various sums.

In the stage of formula validation, the first group could build an intellectual validation while the second could not exceed naive empiricism. (p. 299)

Along this line of thought, it is preferable to consolidate numerical thinking through activities where the spontaneous or functional representations of pupils are considered, and to promote their evolution to the institutional representations (see diSessa, 1991; GonzalezMartin et al., 2008; Hitt, 2003, 2004, 2006).

According to Hitt (2006), a functional representation is as follows:

On one hand, we defined functional representations as the spontaneous representations that a pupil uses in a mathematical situation. On the other hand, we call institutional representations those representations found in books or on computer screens, or those used by teachers when explaining to pupils on the blackboard... In this study, a conception is personal knowledge, constructed by an individual, personally or in social interaction, that is not equivalent to institutionalized knowledge. It is possible to detect a person's conception through the spontaneous representations a person uses when solving a mathematical task. (pp. 255-256)

Based on this, a research project was developed in 2005 to better understand the spontaneous representations used by pupils in grades 8 and 9 in the process of learning the concept 
of co-variation, as a prelude to the concept of function (see Carlson, 2002). The first results are given in a master thesis (Passaro, 2007) and in Hitt and Passaro (2007). Taking into account those results, a group of researchers in Montréal (Canada) have started another research project as a continuation of the previous one: the aim is to develop mathematical activities for grade 9 following Quebec's new program (MELS, 2007) and the new textbooks published after this reform.

\section{Method}

\section{Participants}

In this collaborative research, following the Desgagné et al. methodology (2001), we show how to promote advanced numerical-algebraic thinking in an experiment using certain activities (problem situations) with two class groups (grade 9), following a specific methodology described below.

\section{Instruments}

The activities we designed for our study were:

a) The Photographer was designed to promote use of the following representations: natural language, a drawing to explain the phenomenon, and an abstraction of this drawing that could reflect the idea of covariational reasoning involved in the situation.

b) The Hiker asks the pupils to produce the same representations as in a), but they are also asked to produce a new and different representation to illustrate the same phenomenon. At this stage, pupils are supposed to produce a standard graphic representation related to the situation. A process of validation is required to reject representations that are not useful and to keep the representations that pupils think are useful. If they are able to produce a graphic representation, we ask them to perform the inverse process, and move from the model to the real situation.

c) The Jacuzzi asks pupils to produce the same representations as in b). Additionally, because of the numerical data that appear, we indirectly suggest the use of tabular and algebraic representations.

d) The Squares in Movement activity is necessary to start the process of institutionalization, where all the representations discussed in a), b), and c) are required. 
e) The Shadows activity has a similar objective to Squares in Movement. At this stage, pupils strengthen their knowledge, and the algebraic representations are more difficult to ascertain than those appearing in the previous activities.

\section{Procedure}

The experimentation we followed is a cross-cultural approach for the construction of mathematical concepts. The methodology incorporates the collaborative learning approach (Dillenbourg, 1999), scientific debate (Legrand, 1993, 2001) and self-reflective reasoning (Hadamard, 1975); we call this particular methodology ACODESA (see Hitt, 2007). In summary, this methodology identifies five stages (for more information, see Hitt, 2007):

1. Individual work (so as to not initiate teamwork without a preliminary reflection),

2. Work with peers and material (the first steps of argumentation and validation are generated here). The forming of pairs or triads can vary according to characteristics of the population,

3. Debate (possibly a scientific debate could emerge in the discussion, it is important to continue with processes of argumentation and validation). At this stage, the teacher collects all the material produced by the pupils,

4. Self-reflective reasoning (individual work to reconstruct the work done in previous stages; this can be done at home),

5. Institutionalization. The teacher initiates the institutionalization process as the final stage.

Numerical-algebraic thinking: making the connection between numerical and algebraic thinking

As stated above, we followed a cross-cultural approach, using the ACODESA methodology, to promote advanced numerical-algebraic thinking. Specifically, we promoted a connection between numerical and algebraic thinking through 5 activities that we developed for ninth-grade pupils in Québec.

We took into consideration research conducted by Carlson (2002, p. 64). She states that in order to develop the concept of function, it is first necessary to develop covariational reasoning: covariational reasoning refers to the cognitive activities involved in coordinating two varying quantities while attending to the ways in which they change in relation to each 
other. Our 2005 research project supported this sequence, and our aim was to further elaborate this point of view in the 2007 research project.

The intent of these activities was to develop the concept of covariational reasoning in ninth-grade pupils. We worked with a teacher in a collaborative research approach (see Desgangé et al., 2001) — that is, the researchers discuss the theoretical approach and the activities with the teacher, creating dialectic between research and practice (the teacher thinking as a researcher and the researchers thinking as practitioners). The activities are framed, according Québec's program (Ministère de l'Éducation du Loisir et du Sport, 2007), around a "problem situation". The authors of this program have been influenced by the French school (Brousseau, 1997; Duval, 1993 \& 1995). In practice, however, the authors did not take into account Brousseau's notion of epistemological obstacle; in fact, their "problem-situations" approach is more related to Romberg's approach (1994). We encourage connections among representations in the sense of Duval (1995), but we first consider Hitt's $(2003,2004)$ ideas about functional representations.

\section{Analysis of an episode}

For this study we focus exclusively on the final, Shadows activity:

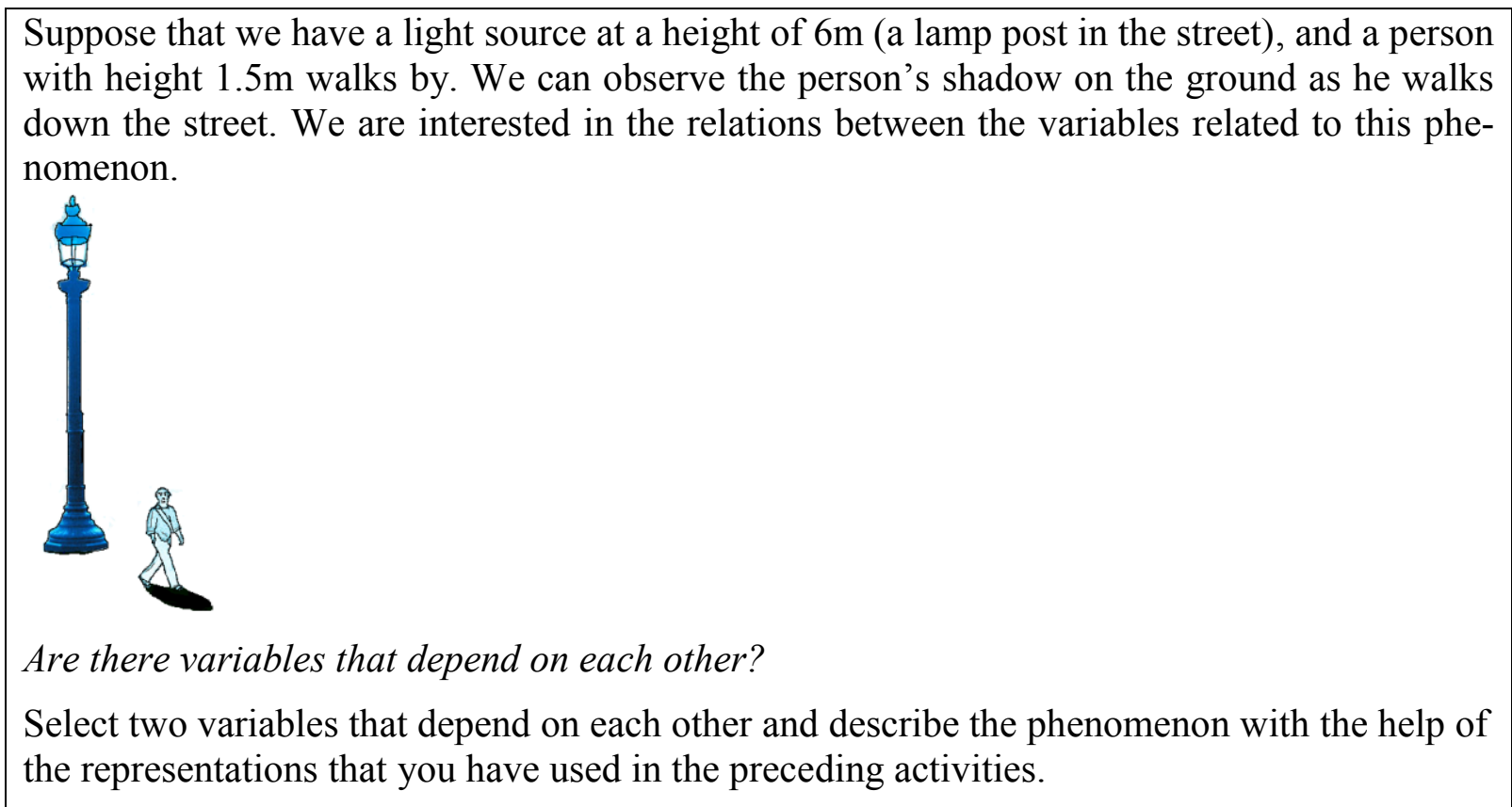

Figure 2. Activity used in Gonzalez et al. (2008), research 
During this last activity, we found that one two-pupil team, seated in the last row of the classroom, did not respect instructions to produce a verbal representation, and from there, with the use of ad hoc materials, to produce a graphic representation before initiating the algebraic process. Instead, this team chose to start the activity with the algebraic representation.

For these two pupils, the algebraic representation is the representation and the rest of the representations were not relevant to them. These pupils had been schooled abroad in different educational systems, and according to their training, the algebraic representation is high-priority. These pupils committed algebraic errors that did not allow them to find the solution for the problem situation in their first attempts.

One of them, after several unfruitful attempts, walked to where another team was, at the front of the classroom. Without wanting to show that he still had not solved the problem, he asked one girl if she and her classmate had solved the activity. This girl, in fact, had been blocked a moment before, and couldn't get through the activity. However, with the numerical explanations of her classmate, she finally found the solution. She answered the boy that yes, there is a proportional relation between the two variables, and the relation provides a straight line as a graphical representation. She also mentioned to him that the dependent variable is one third of the other. He returned to his seat, and once he knew the result obtained by the two girls, from a numerical point of view, along with his companion, they obtained an algebraic answer. When the teacher asked them to explain their procedure to the rest of the class, this pair of pupils surprised the whole class. Nobody had realized, including the teacher, that after their blockage in the algebraic procedure, they overcame the obstacle thanks to the numerical approach of the two girls. In the end, they had made a connection between numerical thinking and algebraic thinking (Figure 3). 


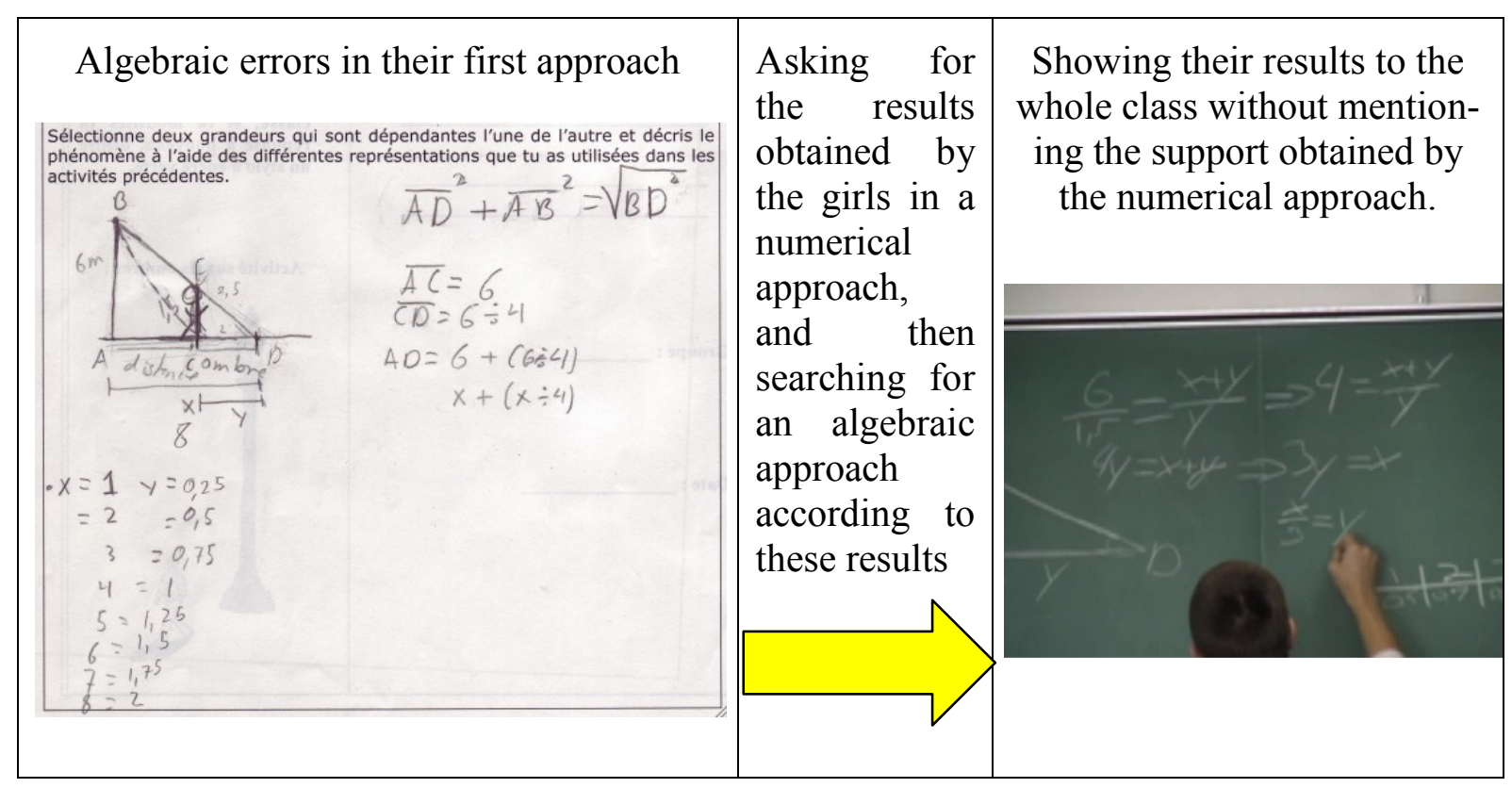

Figure 3. From algebraic errors to an algebraic result supported by a numerical approach

\section{Discussion}

The first thing we want to stress is that numerical reasoning is essential to giving meaning to the syntactic processes that, if manipulated or conceived of incorrectly, can lead to an error in a given situation. Whereas from a syntactic point of view, it may not be possible for us to be aware of our error, the semantic point of view, provided through numerical reasoning, can help bring us to that awareness. The connection between numerical thinking and algebraic thinking can provide us with an element of control along the lines of Barallobres (2004) and Saboya et al., (2006), assuring us that what we are doing follows a line of suitable reasoning, or that it does not.

It is fundamental to develop advanced numerical-algebraic thinking that can serve the pupil as a control element to undergird his algebraic processes; this enables the pupil to be more successful in the learning of mathematics. To promote algebraic thinking in the pupil in isolation from numerical thinking can constitute an obstacle in the long run, particularly for those pupils that cannot master algebraic processes and at the same time are losing their arithmetical abilities. With respect to the resolution of inequalities, Kouki $(2006,2008)$ indicates that the connection between the graphical and algebraic representation has to do essen- 
tially with semantic and syntactic articulation. In our case, we are dealing with the connection between numerical thinking and algebraic thinking.

For example, when we ask an expert pupil in algebra to solve a problem like the following one without using algebra, he is likely to have trouble: with the passing of time, he has probably replaced his numerical abilities with algebraic ones.

If I buy 10 apples I have $\$ 1.50$ left. In order to buy a total of 25 apples, I need $\$ 1.50$ more. What is the price of an apple?

Recent studies are pointing out the problems people have as years pass; the pupils forget what they have learned. As Karsenty (2003) shows in his study concerning adults, when taking a significant population of adults who had chosen sciences in high school and interviewing them some years later, they could not remember how to sketch the graph of a function such as: $f(x)=x$ or $f(x)=2 x$. From our point of view, Carraher et al. are imposing institutional representations, and, in the long term, pupils will forget what they did. In the case of Barallobres (2004), the pupils will probably be able to reconstruct what they did. In Barallobres's (Idem) case, a self-reflective reasoning phase is missing, the phase we proposed in our methodology to see whether the consensus is permanent or momentary.

Finally, we think that working with manipulative materials (like cord, sticks, solder iron, etc.) and producing functional representations that can evolve into institutional ones, and working through collaborative learning, scientific debate and self-reflective reasoning (ACODESA methodology), we can help pupils more easily retain their mathematical constructions. And if we work with teachers in collaborative research, both the researchers and the teachers gain a better understanding of the problem of learning and teaching mathematics.

\section{Acknowledgments}

Special thanks are extended to Alejandro González-Martín (Université de Montréal) for their contributions as part of the subgroup in the task-design process and to Denis Tanguay, Gustavo Barallobres and Stéphane Cyr (Université du Québec à Montréal) for their contribution to the general project as part of the group. The research presented in this article was made possible by a grant from the Fonds de la Recherche sur la Societé et la Culture du Québec (Grant \# 008-SE-118696). We express our appreciation as well to the students who participated in the research. 


\section{References}

Balacheff, N. (1987). Processus de preuves et situations de validation. Educational Studies in Mathematics, 18(2), 147-176.

Barallobres, G. (2004). La validation intellectuelle dans l'enseignement introductive de l'algebre. Researches en Didactique des Mathématiques, 24(2-3), 285-328.

Brousseau, G. (1997). Theory of Didactical Situations in Mathematics. In N. Balacheff, M. Cooper, R. Sutherland \& V. Warfield (Eds.). Dordrecht: Kluwer.

Carlson, Marilyn P. (2002). Physical enactment: a powerful representational tool for understanding the nature of covarying relationships. In F. Hitt (Ed.), Representations and mathematics visualization (pp. 63-77). Special issue of PME-NA and Cinvestav-IPN.

Carraher, D., Schliemann A., \& Brizuela B. M. (2000). Early algebra, early arithmetic: Treating Operations as Functions. Annex to the PME-NA XXII proceedings (pp. 1-24), Tucson, Arizona, USA.

Carraher, D. W., Schliemann, A. D., Brizuela, B. M., \& Earnest, D. (2006). Arithmetic and algebra in early mathematics education. Journal for Research in Mathematics Education, 37(2), 87-115.

Carton, A., Marthouret, L. \& Ryckebusch, S. (2001/2002). Analyse des erreurs des élèves en mathématiques. Unpublished professional repòrt, IUEF, Nord Pas de Calais. France.

Davidson, N. (1998). L'apprentissage coopératif et en collaboration. Une tentative d'unification, in J. Thousand, R. Villa, et A. Nevin (Eds.), La créativité et l'apprentissage coopératif (pp. 63-101). Québec: Les Éditions Logiques.

Desgagné S., Bednardz N., Couture C., Poirier L., \& Lebouis P. (2001). L’approche collaborative de recherché en education: un rapport nouveau à établir entre recherché et formation. Revue des Sciences de l'éducation, 27(1), 33-64.

Dillenbourg, P. (1999). What do you mean by collaborative learning? In P. Dillenbourg (Ed.), Collaborative Learning : Cognitive and computational approaches (pp. 1-19), Amsterdam : Elsevier Science/Pergamon.

diSessa, A., Hammer, D., Sherin, B. \& Kolpakowski, T. (1991). Inventing graphing : Metarepresentational expertise in Children. Journal of Mathematical Behavior, 10, 117-160.

Donovan S., \& Pellegrino J. (2003). Learning and instruction: a SERP research agenda. Washington, D. C.: The National Academic Press.

Duval, R. (1993). Registres de représentation sémiotique et fonctionnement cognitif de la pensée. Annales de Didactique et de Sciences Cognitives, 5, 37-65. 
Duval, R. (1995). Sémiosis et pensée humaine: Registres sémiotiques et apprentissage intellectuels. Suisse: Peter Lang.

Gonzalez, A., Hitt, F., \& Morasse, C. (2008). The introduction of the graphic representation of functions through the concepts co-variation and spontaneous representations. A case study. In Figueras, O. \& Sepúlveda, A. (Eds.). Proceedings of the Joint Meeting of the 32nd Conference of the International Group for the Psychology of Mathematics Education, and the XX North American Chapter (Vol. 3, pp. 89-97). Morelia: PME.

Hadamard, J. (1975). Essai sur la psychologie de l'invention dans les domaines mathématiques. Paris: Gauthier-Villards.

Hatano G., Amaiwa S., \& Inagaki K. (1996). "Buggy algorithms" as attractive variants. Journal of Mathematical Behavior, 15, 285-302.

Hitt, F. (2003). Le caractère fonctionnel des representations. Annales de Didactique et de sciences cognitives, 8, 975-999.

Hitt, F. (2004). Les représentations sémiotiques dans l'apprentissage de concepts mathématiques et leur rôle dans une démarche heuristique. In G. Lemoyne (Ed.), Le langage dans l'enseignement et l'apprentissage des mathématiques : complexité et diversité des cadres d'étude. Revue des Sciences de l'Éducation. Vol. XXX, n. 2, pp. 329-354.

Hitt, F. 2006. Students' functional representations and conceptions in the construction of mathematical concepts. An example: The concept of limit. Annales de Didactique et de Sciences Cognitives, 11, 253-268.

Hitt, F. (2007). Utilisation de calculatrices symboliques dans le cadre d'une méthode d'apprentissage collaboratif, de débat scientifique et d'auto-réflexion. In M. Baron, D. Guin, \& L. Trouche (Eds.), Environnements informatisés et ressources numériques pour l'apprentissage. Conception et usages, regards croisés (pp. 65-88). Paris: Hermes.

Hitt, F., \& Passaro V. (2007). De la résolution de problèmes à la résolution de situations problèmes : le rôle des représentations spontánnées. Actes de la Commission Internationale pour l'Étude et l'Amélioration de l'Enseignement des Mathématiques (CIEAEM59, pp. 117-123). Dobogókö.

Kaput J. (1990). Images of achievable technological future. Proceedings of the fourteenth PME Conference. 1, p. 228. Mexico.

Kaput J. (1998). Transforming algebra from an engine of inequity to an engine of mathematical power by "algebrafying" the K-12 curriculum. In the National Council of Teachers of Mathematics \& the Mathematical Sciences Education Board (eds.), The nature and 
role of algebra in the K-14 curriculum: Proceedings of a national symposium (pp. 2526). Washington, D. C.: National Research Council, National Academic Press.

Karsenty, R. (2003). What adults remember from their high school mathematics. The case of linear functions. Educational Studies in Mathematics, 51, 117-144.

Kouki, R. (2006). L'articulation syntaxe/sémantique au cœur des analyses didactiques au niveau de l'algèbre élémentaire? Actes du colloque Espace Mathématique francophone, Thème 8. Sherbrooke.

Kouki, R. (2008). Enseignement et apprentissage des équations, inéquations et fonctions au secondaire: entre syntaxe et sémantique. Thèse de doctorat, Université de Lyon 1. France.

Legrand, M. (1993). Debate scientifique en cours de mathématiques et especificité de l'analyse, Repères, 10, 123-159.

Legrand, M. (2001). Scientific debate in mathematics courses. In D. Holton (Ed.) The teaching and learning of mathematics at university level: An ICMI Study (pp. 127-135). Dordretch: Kluwer Academic Publishers.

Ministère de l'Éducation du Loisir et du Sport (MELS). (2007). Programme de Formation, Deuxième Cycle du Secondaire. http://www.mels.gouv.qc.ca/DGFJ/dp/menusec.htm.

Passaro, V. (2007). Étude expérimentale sur le développement du concept de covariation entre deux grandeurs revéle par une analyse des représentations spontanées d'élèves du premier cycle du secondaire. Mémoire de Maîtrise, non publié. Montréal: Université du Québec à Montréal (UQÀM).

Romberg, T. (1994). Classroom instruction that fosters mathematical thinking and problem solving: Connections between theory and practice. In A. H. Schoenfeld (Ed.), Mathematical Thinking and Problem Solving. Hillsdale: Lawrence Erlbaum Associates Publishers.

Saboya, M., Bednardz, N. \& Hitt, F. (2006). Le contrôle sur l'activité mathématique comme constitutif de la rationalité en mathématiques: élaboration d'un cadre de référence. Actes du colloque Espace Mathématique Francophone, Theme 8, Sherbrooke.

Tall D. (2008). James J. Kaput (1942-2005), imagineer and futurologist of mathematics education. Educational Studies in Mathematics, 68, 185-193.

Verschaffel, L. \& De Corte, E. (1996). Number and arithmetic. In A. J. Bishop et al. (Eds.), International handbook of mathematical education (p. 99-137). Dordretch: Kluwer Academic Publishers. 